\title{
Nigerian Citizens and Fundamental Rights: Myth, Manoeuvre and Reality
}

\author{
Isah Mohammed Shehu, Nazariah Osman \& Muhammad Fuad Othman \\ School of International Studies \\ College of Law, Government and International Studies \\ Universiti Utara Malaysia \\ zababa72@yahoo.com;nazariah@uum.edu.my;mfuad@uum.edu.my \\ DOI: https://doi.org/10.32890/jis2016.12.4
}

Abstract

Fundamental rights have importance, concern and challenges to societies and states at local and international levels. Those are, however, more in developing states and democracies. Many Nigerian citizens especially civilians and the poor have gone into despair for most of the citizens' rights exist only on paper and are not realistic. This paper investigated the fundamental rights of Nigerian citizens: provisions, enforcement, and myth in these rights; reality and manoeuvre by various stake holders in human rights provisions; enforcement and safeguard. The study used secondary sources of data. It is found that fundamental rights provisions and enforcement in Nigeria are constrained by military rule, poor or no political will and commitment, poor constitutional provisions, poor legal aid and services, ignorance of the existing laws and provisions, deliberate acts to thwart the arm of justice, corruption, judicial incompetence, inefficient justice system, socio-cultural provisions, poverty, state aligned threats and intimidations. The study recommends extensive and intensive education and enlightenment to citizens, full monitoring and strict compliance with provisions on rights, broader and functional legal aid services especially to the poor and the ignorant, revamping Nigeria's justice system to reflect current realities and strict compliance with the rules of engagement by the armed forces, and reviewing laws such as the Penal and Criminal code laws to co-opt new trends and realities.

Keywords: Citizens, constitution, fundamental rights, justice and law.

\section{Introduction}

Humankind, as a higher social animal, is naturally created with an inbuilt desire for the maximisation of pleasure and the minimization of pains (felicific calculus) and also with certain natural and inalienable rights. The exercise and guarantee of these rights are however, largely determined by the environment and other factors within and around which one lives. From the hunting and gathering society to the era of modern and developed democracies, humankind has been, at one instance or the other, grappling with the issue of freedom to exercise or do what he or she wants at liberty. Over the course of history however, 
these liberties, observed and guaranteed, are to a large or small extent influenced by other factors such as religion, culture, socio-economic and environment. In the course of sociocultural, political and religious settings, the formation of the Nigerian state in January 1914 has brought a fundamental change in the socio-economic, cultural and religious settings of the later Nigerian people as the amalgamation came with the imposition of Western alien culture, values and life on the various people of Nigeria. One such imposition was the introduction of a legal system with values of the then emerging industrial society. Akinbiyi (2003) has specifically noted that the introduced alien English law as Nigerian law consists of the Common Law, doctrines of equity, statutes and subsidiary legislation. From the colonial days to the present era, Nigeria has undergone tremendous changes in its legal aspects of life as a state. With the evolution of constitutions and the growth of democracy, issues of fundamental rights came to be entrenched and institutionalized in our legal systems and government. Although all governments whether military or democratic know about the existence and importance of such rights. The extents to which they observe, safeguard and allow citizens to exercise these rights vary from one to the other depending on interest, specific issues and circumstances.

\section{Problem Statement}

Issues of human rights institutionalisation, enforcement, compliance and abuse have occupied much discourse in many circles - civil society, the military (violation of engagement rules), religious groups and institutions as well as the state itself. Abuses of rights by law enforcement agencies, individuals, organizations within the public and private sectors are now common and everywhere in Nigeria. The Judiciary is generally seen to be inefficient in safeguarding of these rights; the public is losing confidence in law enforcement agencies to safeguard the rights; the constitution is also seen as being unable to bridge the gap between its provisions and the reality on the ground; the public is negatively hit by the ignorance of or negligence to its constitutional rights; while the rights are also circumvented, misinterpreted to suit selfish ends resulting in a travesty of justice to one and indeed to all. Although these rights are there provided by the laws, religious and socio-societal structures, Nigerians have to struggle everywhere with other individuals and authorities to actualise and make others to respect the rights (Ajayi \& George, 2002) and there arise certain concerns and challenges in the process.

\section{Theoretical Framework}

This study is framed on the theory of Natural Law (the autonomous individual) which is associated with Hellenistic and Roman periods. The natural law theory is premised on principles of justice and right reasons which are natural, unchangeable and eternal. Natural theory is the most commonly accepted theory of and associated with rights with the substantial work of John Lock who developed the philosophy of humanism and political activity; that people are human beings who are all equal and worthy of basic respects (Hoffman \& Rowe, 
2006; Davis, 2012). The theory simply envisages that humankind was previously living in the state of nature with freedom (rights) to determine self actions, equality, and none was subjected to the whims of the others. But with emergence of some vulnerabilities and hassles which later characterised the state of nature, people got into an agreement (contract) to form a political authority in order to regulate their conducts and also ensure the protection of their natural rights which include life, property, liberty etc. (Dixon \& McCoquodale, 2003; Shaw, 2003; Hamid, 2007).

\section{Review of Related Literature}

Susan (2009) maintains that right refers to those entitlements of all people irrespective of their location, status, other contexts and legal systems. Jewa (2006) sees rights as inherent in man's nature without which he cannot live as a human being. He further maintained that human rights and fundamental liberties are synonymous and they altogether allow man to fully develop and use human qualities, intelligence and talents and conscience to satisfy both spiritual and temporal needs. Hoffman \& Rowe (2006) summarized the meaning of rights as: a claim to something which someone has to do or provide; freedom to do something; power to do something which affects other people; and immunity from challenge in doing something. Right is a very broad and significant social, political, national and international issue and value. As noted by Sriram, Herman, J., \& Martin-Ortega (2009) and Turner \& Morgan (2009) rights although universal, have no universally accepted definition of content and are more globalising. Ajayi and George (2002) have asserted that rights are not absolute and can only be enjoyed within the boundaries and or scopes established by the law. On the other hand, Ladan (2010) has affirmed that irrespective of whatever differences, every human person under Shariah has the basic human rights which are granted by the Almighty Allah (SWT) - the creator of all, and these rights cannot be taken away by any government or ruler and that Islam has in addition accorded special rights to women and children such as those of protection of honour.

Issues related to rights are very delicate and often controversial to define but they have to be addressed as maintained by Knippers (2009) and Davis (2012). However, the extents to which rights are sought, pursued and are observed vary from one time and circumstance to another and dependent on other factors as stated by Falk (2009) that the contours of human rights reflect the moral urgencies of the human condition. This explains the ever widening scope and limitation of rights which among others transform to the guarantee of rights for example - same sex marriage further tying rights, to changing human moral conditions. However, culture, social structure and religion have significant influences and effects on rights and have for long been influencing rights in Nigeria as observed by Egede (2007) that cultural and religious beliefs and values have effects on the effective application of human rights in Nigeria. It is similarly confirmed that most breaches of human rights are caused and or committed by that states against their own citizens or persons in their jurisdiction as a result of certain actions and inactions (Dixon \&McCoquodale, 2003). 
Ajayi \& George (2002) have noted that the development and inclusion of modern human rights in the Nigerian state was, at its foundation, consistent with the British attitude towards human rights. Hamid, (2007) categorised the rights into three types: civil and political (natural rights); economic, social and cultural, and group or people's rights. He further maintained that these three are distinct but mostly confusingly expressed. Hillier (1998) also referred to civil and political rights as the First Generation rights while those of economic, social and cultural as the Second Generation rights. He also identified and termed rights to self-determination and development as the Third Generation rights, adding that the third generation rights are collective - belonging to people rather than individuals. Human rights are natural, inherent and innate in every individual bone and such rights are divine and given to every person. This is so because man is created with rights and no individual needs anything to be able to exercise his human and fundamental rights such as those of life, dignity, personal liberty and private life, association, thought and conscience, movement and religion among others (Malemi, 2010). But there are instances when the definition of rights and violations become subjects of controversy. One such instance is the definition of torture which only the United Nations Convention on Prohibition of Torture, other Cruel, Inhuman and or Degrading Treatment and Punishments, popularly known as the Convention against Torture has come up with a concrete definition. It defined torture as any act through which physical, mental or psychological injury or harm is intentionally inflicted on an individual for the purpose of or with the aim of extracting information, punishing an individual for what he is suspected to have committed, or intimidating or coercing a person to extract information or make individual plead guilty by public officials. But this is exclusive of any damage or injury as a result of a sentence or any lawful sanction executed on an individual (UN Article 1, Doc. A/39/51, 1985). But it is very clear that the states interpret it differently especially in relation to their vested interests while the various national and international human rights organisations and activists see it from another perspective with political, religious and social cultural undertones.

\section{Enforcement and Compliance with Rights}

Enforcement and compliance with human rights has generally been a major challenge and source of concern to both citizens and the states especially in developing democracies. Some of the challenges involve: interpretation and enforcement of the original constitutional provisions, political will and determination to enforce and ensure compliance; influences of religious and non-governmental organisations, international laws/conventions/declarations and domestication of such. But all the same, as noted by Bunyard (1978) they have to reach a balance between allowing total freedom for the citizens and limiting the rights so as to and at the same time, be able to maintain law and order of the state and regulate citizens behaviours. Sriram et al. (2009) lamented that that rights are human and bound to be violated especially during conflicts of violation of rights as a cause and also as consequences of multi-dimensioned conflicts in a society. 
On December 10, 1948, the United Nations Organization adopted the bill on human rights through resolution 217a (111). By that act, the Universal Declaration of Human Rights was established which placed human rights on a global agenda, certified its universality and to some extent universal acceptability. This stimulated regional bodies like those in Europe to declare conventions for the protection of human rights and fundamental freedom in 1950 and 1969 respectively. From then on, other states, regional and continental bodies took the queue from Europe and America in adopting the universal human rights declaration. On the African continent, the Charter on human rights was adopted in 1981 and it came into force in 1986. By the provisions of the Constitution of Nigeria, all her citizens have rights to life, own properties, fair hearing and freedoms of speech, religion, association, movement and many others (Section 33 of the 1999 Constitution of the Federal Republic of Nigeria). These rights are not to be infringed upon by any individual, government, association or organisation. Even where punishments are to be made as may be provided by the law, the essence of such punishment, in whatever form, is deterrence, rehabilitation, public protection, and any pain of punishment should be linked to a positive outcome based on the rational theory of punishment of Jeremy Bentham as affirmed by Susan (2009).

\section{Fundamental Rights and their Violation in Nigeria}

The various Nigerian Constitutions have made clear provisions on the fundamental rights of citizens. For example, Chapter IV of the 1999 Constitution of the Federal Republic of Nigeria spelt out the various rights and provided for their safeguard, guarantee and enforcement. It additionally provided the only grounds on which such rights can be deprived. But in Nigeria, human rights violation is pronounced in all aspects of the citizens' life (both public and private). Violation of the rights is however, a result of several factors and from within the government (the justice system, other law enforcement agencies and civil-public agencies) and the general public through many actions, inactions and reactions as well as socio-societal, cultural, religious and economic factors which also account for the problems associated with the fundamental rights in Nigeria.

\section{The Nigerian Armed Forces, Judiciary and Enforcement of Fundamental Rights}

The Nigerian Armed Forces which have dominated a substantial period of Nigeria's post independence era have immensely contributed to the debacle of the fundamental rights exercise, safeguard, enforcement and promotion. The Military has intervened and abolished political systems, regimes and disrupted democratic processes about seven times. Each time they intervened, the rights and constitutional laws were replaced or rather more twisted with supreme military decrees and edicts that were not challengeable in any constitutional court of law. Suspension and or abolition of constitutional laws is further intensified by the promulgation of unpopular military decrees and edicts which empower the military and their respective regimes to circumvent, trespass and or trample on the fundamental rights of citizens especially where a clash of interest or policy between popular constitutional laws 
and rights on one hand and interests or policies which the military is bent on protecting or implementing on the other occurs. Several decrees such as those (Press, 1984) are still fresh in the minds of the Nigerian citizens in addition to daily assaults, torture, manhandling and authoritarian tendencies manifested by the various military regimes. The Nigerian military did not only hinder the actualization of enforcement and compliance with the rights of the Nigerians but have also uprooted the stems of the institutionalised process of providing, safeguarding and enforcing these rights in the constitutional and democratic establishment and settings.

The Courts are an integral part of the Nigerian justice system with a very strategic role to play as the last resort and hope for every citizen seeking redress and justice in Nigeria. The Courts are therefore, also strategically involved in the safeguard, enforcement and compliance with rights of the Nigerian citizens. According to Ajomo \& Okagbue, (1991:195), the courts are also an integral part of the problem of the citizens' fundamental rights as they are responsible for the excessive and unnecessary adjournments of cases, inadequacy of personnel, unlawful arrests and severe conditions attached to bail processes. Peters et al. (2009) have identified the misdoings of courts in Nigeria which deprive, obstruct and breach citizens' rights as: concoction of facts, posing too many and complicated questions during proceedings, unwrapping aggression to either of the parties, holding-up trials/excessive speed during trials, superfluous adjournments, refusing to take or grant applications, refusing to allow/ block reconciliations, withholding trial records, executing judgment instantly to frustrate appeals, converting civil cases to criminal cases/offences, allowing a party to benefit from wrong doing, refusing to grant bail, threatening and intimidating for contempt, and using private information to make court decisions. All these are against the fact that presiding judges have strategic duties of controlling court proceedings, doing justice between parties, upholding the independence of the judiciary and the principles of fair hearing, politeness and courtesy to all, especially the two parties and maintain high standards of behaviour (Akinbiyi, 2003).

The judiciary/courts have strategic roles of guarding and enforcing constitutional limitations on power, guardians and dispensers of justice to all as enshrined in the laws and the resolution of conflicts between individuals and between individuals and the state (Nwabueze, 2007). Similarly, it is expected that the rights of an accused person in a trial pre-trial which includes those of life, human dignity, personal liberty, fair hearing/natural justice and post trial which are inclusive of all constitutional rights are to be protected (Malemi, 2010). Likewise, the objectives of sending one to prison are generally for the reformation of character, punishment and containment of the offender, imprisonment to deprive the individual of his/her certain rights but all with the intent of correcting the person and preventing him from doing such or any other wrong in future (Sanda, 2007). But all these provisions are contrary to the current Nigerian judiciary. Part of the Judicial problems in the issue of citizens' rights have to do with what Beredugo (2009) and Olong (2009) have decried as the conflict of laws and the law courts themselves over decisions on the enforcement/interpretation of rights. 
The Nigerian Police is the only police force (for Nigeria) established under Section (214) of the 1999 Constitution of Nigeria which also spells out its major functions as contained in Section (4) of the Police Act as: prevention and detection of crime, apprehension of law offenders, preservation of public laws and orders, enforcement of laws, protection of lives and properties and performance of other military services upon requirement. The police force is essential to any and every justice system with the assignment of arrests and prosecution of suspects and enforcement of laws. In line with that, Section 4, Part I of the Police Act 2004, provides that the Nigerian Police Force shall ensure prevention and detection of crime, apprehend offenders and preserve laws and order of the Federal Republic of Nigeria, protect the lives and properties of Nigerians and perform other military duties outside Nigeria when they are required to do so. The police is vested with enormous powers, but the powers to carry out some of their duties such as search, suspect and arrest are largely dependent on circumstances (de Than \& Shorts, 2013). It is also on such grounds that the rights of citizens are abused. As far as the Nigerian police force is involved, many of the rights abuses are attributed to it with deliberate acts both overt and covert such as refusal to clearly explain the terms of the Miranda Warning to those arrested and or suspected of offences. The Miranda vs Arizona, 384 U. S. 436, 86 S. Ct. 1602, 16 L. Ed. 2d 694 (1966) which has to do with the rights to remain silent and be entitled to the presence of one's lawyer during the police interrogation is in most circumstances deliberately hindered by the Police (Wilson \& Key, 2011). This (Miranda) warning/statement is to be made or fully explained to anyone before he/she is subjected to further questioning/interrogation by the police: You have the right to remain silent; anything you say can be used against you in court; you have the right to talk to a lawyer of your own choice before questioning; if you cannot afford to hire a lawyer, a lawyer will be provided without any charge (Janda, 2012). The Miranda warning has a strategic significance in both safeguarding the rights and complying with constitutional provisions on the rights as indicated by the United States Supreme Court when it held in 1966 that criminal suspects in police custody must be advised of certain rights to protect themselves against self- incrimination (Miranda vs Arizona, 1966). Thus, the Miranda rights became extended to all adult suspects, nations and states. The suspects generally misunderstand or do not take any significance in the Miranda warnings and the language expressions used by the police as lamented by Grisso (1981).

\section{The Nigerian Context of Fundamental Rights Conception, Enforcement and Abuse}

At most times there exists confusion and or complexity as to the definition and dimensions of a particular right and discretion of the law agencies to enforcement, and limits to such rights as those of privacy and religion as observed by Fisher (1990). As human rights violations occur within the states and their jurisdictions, effective protection, enforcement and promotion must also come from within the state as observed by Steiner \& Alston (2000). Enforcement of rights is also conceived and interpreted from environmental, cultural and socio-societal perspectives, thus the controversy on the rights of the children, women, gays and lesbians. These are in addition to the Shariah point of view that freedom to humankind is favour from Allah and a source of honour. Misuse of this freedom is a dishonour and from 
there and then erupts evil and disorderliness. The essence of freedom and its exercise are geared towards honour to humankind and limited to avoidance of evil and disorder (Abbas, 2012a). But the Western world and democracies believe in and maintain the incompatibility of the Sharia and democracy, and there exists an increased challenge to Islam and Muslims on human rights issues as decried by Abbas, (2012b; Hassan, 2012). This is so because the Islamic legal system and rights do not leave the issue of rights to human rationality and desires alone but as concurred by Hallaq (2009) the Islamic legal tradition is that while human reason is to be fully utilised, the content of rotational thinking must be predetermined, transcendental, and above and beyond what we can deduce through our mental faculties. The Islamic point of human rights is hinged basically on what is appropriate and inappropriate conduct within the contest of social, economic, political and other facets of life thereby defining and specifying the standards of ethics, morality and legality (Cook, et al, 2013: 167). There may therefore, be differences in understanding and the enforcement of rights from different perspectives especially between Islam on the one hand and the other religions on the other hand as noted by Khan (2007:134) who related the divergence between Islam and other religious on the allocation of rights to women, children etc. Whatever may be the perspective, everyone has and is entitled to rights including prisoners except where punishment is directly related to such a right (Susan, 2009).

\section{Internationalization and Politics of Rights}

The question of right is a universally controversial and jurisprudential debate and so are also the patterns of commitment and enforcement (Shaw, 2003). This is because human rights issues are now part of international politics and relations of the post cold war era, foreign aid and politics of development and underdevelopment, conventions and diplomacy due to the increasing rate of globalisation. This is unlike the $18^{\text {th }}$ and $19^{\text {th }}$ centuries when there was little international significance and influence largely because of the strongly held belief in the principle of absolute sovereignty of the individual states (Kalin, Muller, \& Wyttenbach, 2004). All the major marketers and promoters of human rights started the pursuit of rights internally within their states before the $21^{\text {st }}$ century politicization and internationalization of human rights - the Virginia Bill of Rights, 1776; the French Declaration of Rights of Man and of the Citizen, 1789; and the Swiss Federal Constitution Declaration, 1874. These were followed by internationalization and regionalization of human rights such as the United Nations (1948) and the European Convention on Human Rights (ECHR) 1950. Over time and with the wave of democratization across the world, and the end of the Cold War as noted by Shawki \& Cox (2009), global attention has largely shifted to achieving and entrenching democracy and human rights, thus, the coming together of several factors such as the states; regional, national and international organisations, elites; gender and civil societies groups, and leaders for the cause. This has taken a new dimension by the $21^{\text {st }}$ century as issues of human rights have become the subject of intense politics and laws which greatly limit the sovereignty of the states as observed by Dixon \& McCorquodale (2003). Kalin et al (2004: 17) \& Hamid (2007) who added that the attention of the world has been drawn to human rights as a result of the terrors of socialism and the horrors of the Second World War, thus 
the rooting of human rights in the United Nations' Charter. The United Nations Universal Declaration of Human Rights (Article 1 \&2) of December 10, 1948, for example, provides that: all human beings who are born free and have equal dignity and rights and are endowed with reasoning and conscience, should thus act with spirit of brotherhood; all are entitled to rights without difference of race, colour and religion irrespective of politics, social origin or birth circumstances.

\section{The Way Forward}

For the fundamental rights to be fully safeguarded, enforced and complied with in Nigeria, this study has made the following recommendations:

1. State actors and components of the Nigerian justice system should all have genuine commitment and political will to safeguard, enforce and comply with the provisions on Nigerian citizens' rights.

2. Nigerians must stop the 'I don't care' attitude towards the activities of law enforcement agencies and begin to wholly monitor and follow up their rights in all endeavours, and properly handle threats and intimidation by individuals and or authorities.

3. Nigerians should develop the habit of patience and perseverance in pursuing their rights and entitlements especially with regards to other law enforcement agencies and the justice system and not just leave everything to the Almighty God and counting on the last day of judgement.

4. Nigerians should (within the ambit of law) be resistant to any form of rights violation whether by individuals or authorities.

5. There should be all round political will and commitment by the various stakeholders on rights to genuinely safeguard, enforce and ensure compliance with rights provisions as enshrined in the constitution of Nigeria and other related charters.

6. There should be comprehensive and extensive civic education from the grassroots level toeducate and enlighten Nigerians from different categories on the significance of rights and related constitutional provisions for safeguard and enforcement.

7. Provision of legal aid services should be revived and encouraged all over the country.

8. Established legal aid clinics should be accessible to all especially the common and poor people at the lowest societal levels.

9. Educational institutions should be encouraged to form legal and human rights societies and clubs to optimise rights awareness among young students and the citizens generally.

10. More, open and accessible human rights documentation centres should be established especially by nongovernmental organisations to guard against excessive abuse of citizens' rights and document where it occurs for legal and other purposes.

11. The new social media and technology (WhatsApp, Twitter and Instagram etc.) should also be used by subscribers and telecommunication /networks/internet 
service providers to promote the cause for safeguarding, enforcing and complying with rights provisions.

12. Armed forces personnel must be properly oriented on the rules of engagement while on operations and be made to account for their conduct whenever cases of rights violations occur.

\section{Conclusion}

The success of a state is largely measured by its ability to regulate citizens' behaviours and dispense justice to its citizens but these equally depend on the efficiency of its justice system. Institutions are only as strong as the political will of those who govern them. In most cases, those who bear the primary and most important responsibility of safeguarding and enforcing the fundamental rights of the Nigerian citizens are those who actually hinder effective safeguarding and enforcement of rights in Nigeria and human rights violation is cause and consequence of conflict. All the Nigerian constitutions have made vivid provisions for citizens' fundamental rights in addition to adopting other continental and international charters. The various Articles, Charters and constitutional provisions on rights are overt. But despite that, the attempt to achieve, safeguard, enforce and comply with rights in Nigeria still has a long way for its actualisation. Indeed rights violation in Nigeria is very obvious and in many cases those responsible for the safeguarding, enforcement and compliance are to blame; while Nigerian citizens lack of general and basic civic awareness and enlightenment. Intimidation, fear, poverty, corruption, negligence of duty and incompetence are also major factors that are making safeguarding, enforcement and compliance with rights in Nigeria difficult. The Nigerian justice system, law enforcement agencies, religious and socio-cultural and societal values and preferences are equally major stumbling blocks to the safeguarding and enforcement of these rights.

Politicisation of the justice system components (the police, courts and the prison) has also hindered the rights of Nigerian citizens. Security agencies commit human rights violations (in covert and overt instances) with impunity in most of the cases reported. Issues of fundamental rights have a long way to go in Nigeria especially with regards to the political will and commitment of the state actors and the justice system; emerging moral conditions on some controversial rights such as: children's rights, early marriage, same sex marriage, women, equal rights for men and women, socio-societal, traditional and religious rights, values and provisions. Most of the time, the state is not willing to enforce or comply with the rights of citizens especially on issues that may not favour it. For example, in 2015, a non-governmental organisation (SERAP) filed a case against the former Minister of Finance, Mrs. Ngozi Okonjo-Iweala before a Federal High Court sitting in Lagos in May, 2016, praying the court to force her to provide information on N30 trillion which the former minister refused to provide. In its ruling, the court directed the minister and the Federal Government of Nigeria to provide the information as the Freedom of Information Act stipulates that public officers shall either provide the information requested or communicate withholding it within seven days of receipt of the request for such information. This is 
the same with human rights in international relations, politics and investments especially with regards to alien and unpopular conditions, propaganda and indirect undermining of the states' sovereignties in the name of human rights with a major role played by non-state but influential international actors such as the Amnesty and Transparency International.

\section{References}

Abbas, H. (2012a). Islamic law and judiciary. New Delhi: Random Publications.

Abbas, H. (2012b). Islamic law and human rights. New Delhi: Random Publications.

Peters, D., \& Ayua. P. M. (2009). Fair hearing and bail, National Judicial Institute Journal, 2 (1), 32-48.

Akinbiyi, S. (2003). Ethics of legal profession In Nigeria. Abeokuta: Augustus Publication. Ajayi, J. F. A., \& George, Y. A. (2002). Kayode Eso: The making of a judge. Ibadan: Spectrum Books.

Beredugo, A. J. (2009). The Nigerian legal system: An introduction. Lagos: Malthouse Press Limited.

Bunyard, R. S. (1978). Police: Organisation and command. London: Macdonald and Evans. Constitition of the Federal Republic of Nigeria, 1999. Government Printer: Lagos.

Cox, M., \& Shawki, N. (2009). Negotiating sovereignty and human rights: Actors and issues in contemporary human rights politics. Farnham, England: Routledge.

Cook, M,., Haider, N., Rabb, I., \& Sayeed, A. (Eds). (2013). Law and tradition in classical islamic thought. New York: Palmgrave Macmillan.

Davis, H. (2012). Human rights questions \& answers. Essex-England: Pearson Education Limited.

Dixon, M., \& McCorquodale, R. (2003). Cases and materials on international Law. Oxford: Oxford University Press.

De Than, C., \& Shorts, E. (2013). Human rights. Essex- England: Pearson Education Limited.

Egede, E. (2007). Bringing human rights home: An examination of the domestication of human rights treaties in Nigeria. African Law Journal, 51, 249-284.

Falk, R. A. (2009). Achieving human rights. New York: Routledge.

Fisher, L. (1990). Constitutional rights: Civil rights and civil liberties. New York: Mc Graw Hills Inc.

Grisso, T. (1981). Juveniles' waiver of rights: Legal and psychological competence. New York, NY: Plenum.

Hallaq, W. B. (2009). An introduction to Islamic law. London: Cambridge University Press. Hamid, A. G. (2007). Public international law: A practical approach. Selangor Malaysia: Prentice Hall.

Hassan, A. (2012). Contemporary Islamic issues in law. New Delhi: Random Publications. Hillier, T. (1998). Sourcebook on public international law. London: Cavendish Publishing Limited.

Hoffman, D., \& Rowe, QC. J. (2006). Human rights in the UK: An introduction to human rights act 1998. Essex-England: Pearson Education Limited. 
Janda, K., Berry, J. M., \& Goldman, J. (2002). The challenge of democracy. Boston: Houghton Milling Company.

Jewa, T. S. (1996). Public international law: A Malaysian perspective. Kuala Lumpur: Pacifica Publications.

Kalin, W., Muller, L., \& Wyttenbach, J. (Eds). (2004). The face of human rights. Baden Switzerland: Lars Mullers Publishers.

Khan, A. A. (Ed). (2007). Foundations of Islamic law. New Delhi: Pentagon Press.

Knippers, B. J. (2009). The Politics of human rights protection: Moving intervention upstream with impact assessment. Lanham, Md: Rowman \& Littlefield Publishers.

Ladan, M. T. (2010). Introduction to jurisprudence: Classical and Islamic. Lagos: Malthouse Press Limited.

Malemi, E. (2010). The Nigerian constitutional law. Lagos: Princeton Publishing Company.

Nwabueze, B. (2007). The judiciary as the third estate of the realm. Ibadan: Gold Press Limited.

Olong, A. M. (2009). The Nigerian legal system. Lagos: Malthouse Press limited.

Police Act. (2004). Cap. P19 Laws of the federation of Nigeria,

Shaw, M. N. (2003). International law. Cambridge: Cambridge University Press.

Susan, F. (2009). Human rights in the South Pacific: Challenges and changes. London: Routledge - Cavendish.

Sriram, C. L., Herman, J., \& Martin-Ortega, O. (2009). War, conflict and human rights : Theory and practice. London: Routledge.

Steiner, H. J., \& Alston, P. (2004). International human rights in context: Law, politics, morals. London: Oxford University Press.

Turner, B. S., \& Morgan, R. (2009). Interpreting human rights: Social science perspectives. London: Routledge.

United Nations Organisation. (1948). United Nations universal declaration on human rights. New York: United Nations.

Wilson, J., \& Key, K. (Eds). (2011). American law year book, 2010. Detroit: Gale Cengage Learning. 